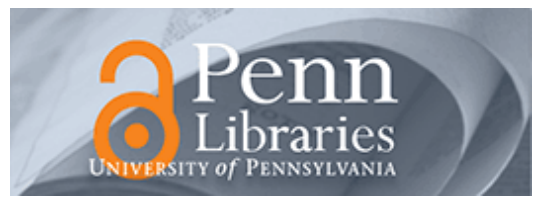

University of Pennsylvania

ScholarlyCommons

Finance Papers

Wharton Faculty Research

2005

\title{
Crossborder Dividend Taxation and the Preferences of Taxable and Nontaxable Investors: Evidence From Canada
}

Susan Elizabeth Kerr Christoffersen

Christopher C. Geczy

University of Pennsylvania

David K. Musto

University of Pennsylvania

Adam V. Reed

Follow this and additional works at: https://repository.upenn.edu/fnce_papers

Part of the Economic Theory Commons, Finance and Financial Management Commons, and the Taxation Commons

\section{Recommended Citation}

Christoffersen, S., Geczy, C. C., Musto, D. K., \& Reed, A. V. (2005). Crossborder Dividend Taxation and the Preferences of Taxable and Nontaxable Investors: Evidence From Canada. Journal of Financial Economics, 78 (1), 121-144. http://dx.doi.org/10.1016/j.jfineco.2004.08.004

This paper is posted at ScholarlyCommons. https://repository.upenn.edu/fnce_papers/388

For more information, please contact repository@pobox.upenn.edu. 


\title{
Crossborder Dividend Taxation and the Preferences of Taxable and Nontaxable Investors: Evidence From Canada
}

\author{
Abstract \\ We consider how fund managers respond to the conflicting preferences of their investors. We focus on \\ the conflict between the taxable and retirement accounts of international funds, which face different \\ tradeoffs between dividends and capital gains. In principle, managers could resolve this conflict through \\ dividend arbitrage, but a proprietary database of dividend-arbitrage transactions shows that in practice \\ they cannot. Thus, managers must resolve it through their investment policies. We find robust evidence \\ that managers with more retirement money favor the preferences of retirement investors and further \\ evidence for this view in the difference between U.S. and Canadian funds' portfolio weights. \\ Disciplines \\ Economic Theory | Finance and Financial Management | Taxation
}




\title{
Cross-border dividend taxation and the preferences of taxable and non-taxable investors: Evidence from Canada
}

\author{
Susan E. K. Christoffersen \\ McGill University and CIRANO \\ Christopher C. Geczy \\ University of Pennsylvania \\ David K. Musto \\ University of Pennsylvania \\ Adam V. Reed \\ The University of North Carolina
}

This Draft: July 29, 2004

\begin{abstract}
We consider how fund managers respond to the conflicting preferences of their investors. We focus on the conflict between the taxable and retirement accounts of international funds, which face different tradeoffs between dividends and capital gains. In principle, managers could resolve this conflict through dividend arbitrage, but a proprietary database of dividend-arbitrage transactions shows that in practice they cannot. Thus, managers must resolve it through their investment policies, and we find robust evidence that managers with more retirement money favor the preferences of retirement investors. We find more evidence for this view in the difference between U.S. and Canadian funds' portfolio weights. JEL classification: G11; G23; H20; F30
\end{abstract}

Correspondence to David K. Musto, Finance Dept., Wharton School, 3620 Locust Walk, Philadelphia PA, 19104; Phone 215-898-4239, e-mail musto@wharton.upenn.edu. The authors thank Marshall Blume, Laurence Booth, Francesca Carrieri, Peter Christoffersen, Jennifer Conrad, René Garcia, Sarah Holden, Bob McDonald, Randall Meades, Jack Mintz, Neal Pearson, Brian Reid, Steve Ross, Doug Shackelford, Rob Stambaugh, and other sources who prefer to remain anonymous. We also are grateful for helpful advice and comments from numerous seminar participants. We are grateful for financial support from SSHRC, FQRSC, IFM2, and the Rodney L. White Center for Financial Research, and for research assistance from Eric Turner, KC Chang, Sarah Coyer, and Victoria Von Krause. 


\title{
Cross-border dividend taxation and the preferences of taxable and non-taxable investors: Evidence from Canada
}

\begin{abstract}
We consider how fund managers respond to the conflicting preferences of their investors. We focus on the conflict between the taxable and retirement accounts of international funds, which face different tradeoffs between dividends and capital gains. In principle, managers could resolve this conflict through dividend arbitrage, but a proprietary database of dividend-arbitrage transactions shows that in practice they cannot. Thus, managers must resolve it through their investment policies, and we find robust evidence that managers with more retirement money favor the preferences of retirement investors. We find more evidence for this view in the difference between U.S. and Canadian funds' portfolio weights.
\end{abstract}




\section{Introduction}

A fund manager is an agent for diverse principals. His investors have something in common, that they chose his fund over others, but they can otherwise vary in what they want from him. One likely source of this variation is the tax code - in particular, its differing treatment of retirement and non-retirement accounts. Dividends and capital gains deliver different after-tax benefits to these two major account types, but the typical fund contains both types. Thus, the typical fund manager must serve these two preferences with one policy.

Retirement money varies in proportion from one fund to the next. This variation creates an opportunity to explore investment policies along a new and important dimension: by relating the variation of retirement money to that of a policy choice that favors retirement money, we can gauge the role of shareholders' preferences in their funds' investment policies. That is our goal in this paper.

Our research question is closest in spirit to that of Barclay, Pearson and Weisbach (1998), who consider an agency problem arising from managers' appetite for new investment. They demonstrate that funds trade off the welfare of their current and prospective taxable accounts in their realization of capital gains, and Bergstresser and Poterba (2002) extend this analysis to the whole range of tax burdens on taxable accounts. We apply their trade-off analysis to the competing interests within a fund's current accounts, the retirement accounts against the non-retirement accounts, and we focus on a policy and a venue where this competition is easily observed.

The policy is dividend yield, and the venue is international equity funds. In this venue, dividend policy trades off retirement and non-retirement accounts because cross- 
border dividends incur a tax which taxable accounts can reclaim as a tax credit, but nontaxable accounts cannot. The result, under the post-2002 tax code, is a stronger aversion to dividends, relative to capital gains, among international funds' retirement accounts than among their non-retirement accounts. Thus, looking across international funds, we see the role of shareholders' preferences in their funds' policies in the relation of retirement money to dividend policy.

A virtue of addressing dividend policy, rather than other tax-related policies, is that it is easily observed. That is, a fund's ex post dividend yield is easily observed, and it is also highly representative of the fund's ex ante dividend policy because dividends are highly predictable. By contrast, a fund's capital gains and capital gains realizations reflect not only ex ante policy but also ensuing price movements, fund flows and reinvestment ideas that are much less predictable, and therefore much less representative of policy decisions.

Cross-border dividend policy has a second dimension which is not so easily observed. This is the dimension of dividend arbitrage, where funds avoid cross-border withholding by lending shares back across the border for their dividend record dates, and splitting the tax savings with the borrower through the lending fee. This tactic converts the tax credit into the lending fee, so it is Pareto-improving only if the fee is at least the credit. Otherwise, it leaves the fund's non-retirement accounts worse off. Thus, the connection between funds' cross-border dividend policies and the relative welfare of their retirement and non-retirement accounts hinges on the pricing of dividend-arbitrage transactions. But while the literature on dividends is extensive, it does not cover this 
pricing, presumably because such data is proprietary. That is where our proprietary database is instrumental.

Our data show the fees that lenders get for their credits, in the case of U.S. lenders of Canadian shares. We see a year of loans of Canadian securities by a large U.S. lending agent, including over $\$ 600 \mathrm{MM}$ of loans on dividend record-dates. This means we can observe the fees, calculate the credits, and thereby observe the crucial pricing: the fees that lenders get for their credits.

Our key finding with the proprietary data is that arbitrage is useful but incomplete. Lending fees convert only some of the tax credit into cash, falling significantly short of the full amount. This shortfall means that cross-border dividends impose a net tax on a mutual fund's retirement accounts, and therefore that the welfare effect of its cross-border dividend policy depends on how much retirement money it serves.

So how do managers resolve this conflict between their account types? We take this question to the cross section of international equity funds. For the funds in our sample we have the proportion of defined-contribution money in its assets, as of year-end 2002, and we have the relevant measures of its cross-border dividend policy in fiscal-year 2003: the dividends paid by its portfolio, and the tax withheld from these dividends. We ask three questions. As retirement money goes up, does dividend yield go down? Does withholding tax go down? And, as dividend-arbitrage activity would imply, does the withholding tax per unit of dividend yield go down?

The answer to all three questions is yes. As retirement money grows, investment policies increasingly favor retirement accounts. This is true, we show, even if we control 
for the subcategories of international funds, both Lipper's index groupings and Morningstar's style boxes, so our finding does not result from retirement investors gravitating toward more-suitable fund types. We also observe that this is contrary to what would happen if managers simply maximized the total returns we observe.

As a robustness check, we repeat the regressions on a sample of domestic funds, where the taxation of retirement accounts is unaffected by dividend yield. If domestic funds' retirement allocations relate to their dividend yields anyhow, then our international-fund results may reflect some other preferences at work. But the regressions find no relation, supporting our explanation for the international-fund results.

The final tests turn from individual funds to aggregate cross-border holdings. This analysis focuses on the U.S./Canada border because it corresponds to the holdings data, and also because - for reasons we detail below - the countries' differing regulations impart differences in after-tax preferences that deliver testable predictions for differences in their holdings. Again, we find the cross-sectional variation of funds' investment policies lines up with the variation in their shareholders' preferences.

The rest of the article is organized as follows. Section 2 describes the data, Section 3 covers the relevant background, Section 4 addresses dividend-arbitrage revenue in Canada and dividend-arbitrage volume in the United Kingdom, Section 5 addresses the cross-sections of international and domestic mutual funds, Section 6 addresses the aggregate portfolios of Canada and the U.S., and Section 7 summarizes and concludes. 


\section{Data}

The equity-lending data is the data used in Geczy, Musto and Reed (2002), where it is described in detail. For the purposes of this study, a few facts are important. First, the data cover some Canadian firms because they cover all U.S.-listed stocks, and some Canadian stocks list in the U.S. These are not ADRs, but rather the same security that trades in Canada (see Eun and Sabherwal, 2003). Second, for each loan we have the lending fee. When the loan collateral is cash, the lending fee is a rebate reduction on interest earned by the lender on the collateral, and when collateral is in-kind, the lending fee is simply a cash payment from the borrower to the lender. The fee is annualized, so when we use it we must de-annualize. Finally, we have one year, 11/98 through 10/99, of data, and the lender is a large U.S. custodian bank with trillions of dollars in custody, so the loan amounts are significant, often in millions or tens of millions of dollars.

In addition to the loan-price database covering US-listed stocks, we also have a loan-volume database covering UK-listed stocks. This data is from CRESTCO, the UK clearing corporation, and it covers the FTSE 250 and FTSE 100 (as well as a few non-UK stocks, which we disregard). For each day and each stock we have the total number of shares held through CRESTCO, which is generally very close to the total shares outstanding of the stock, and we also have the total number of those shares that are out on loan. From Bloomberg we have dividend amounts and record dates for the same stocks.

The sample of international funds starts with data purchased from Pensions and Investments. The periodical surveyed mutual funds, asking them their dollar amount of defined-contribution retirement savings as of $12 / 31 / 02$. This is not precisely the same as all retirement money, because some mutual funds hold some defined-benefit assets as 
well, but the size of the difference appears small. ${ }^{1}$ Of the international funds that responded, we take all funds for which FY 2003 SEC filings and 12/31/02 total net assets are available, and from those we take the 64 funds with at least $\$ 100 \mathrm{M}$ under management as of $12 / 31 / 02$. Note that we do not include global funds, because they invest also in domestic equities, and we are interested only in funds where all dividends are cross-border. This sample represents about half, by dollar value, of the universe of international funds. ${ }^{2}$ For each fund we get its FY 2003 withholding tax and dividend income from the Statement of Operations in its Annual Report, and we get its total net assets as of the beginning, middle and end of FY 2003 from its Annual and Semiannual Reports. Summary statistics of the sample are provided in Table 1 .

For a robustness check of our international-fund results, we collect the analogous sample of domestic funds. From the domestic funds that responded to the P\&I survey we take all funds for which FY 2003 SEC filings and 12/31/02 total net assets are available, and which have at least $\$ 100 \mathrm{M}$ under management as of $12 / 31 / 02$. This yields a sample of 434 funds, and we collect their dividend income and total net assets analogously to the international-fund sample.

The data on portfolio holdings are from two databases compiled by Thomson Financial: the $13 \mathrm{f}$ database and the mutual-fund database. The $13 \mathrm{f}$ database includes both U.S. and Canadian institutions, and shows the holdings of all U.S.-listed stocks by institutions that hold at least $\$ 100 \mathrm{M}$ worth, and that do some business in the U.S.

\footnotetext{
${ }^{1}$ According to the 2003 Mutual Fund Fact Book, \$11BB of the \$158BB of retirement money in foreign equity mutual funds as of 12/31/02 "[i]ncludes 457 plans, private defined benefit plans, state and local government employee retirement funds, Keoghs, and other defined contribution plans without 401(k) features." (p. 56).

${ }^{2}$ According to the 2003 Mutual Fund Fact Book, the sum of International, Emerging Market and Regional (but not Global) funds' assets was \$217.6BB as of 12/31/02, about twice the \$117.1BB in Table 1.
} 
Because, as discussed above, some Canadian firms list in the U.S., this means we see both U.S. and Canadian investment in both U.S. and Canadian stocks. We use the $13 \mathrm{f}$ data for 12/31/2000; the SEC's Official List of $13 f$ Securities for 12/31/2000 lists the stocks that institutions had to disclose. For each of these stocks, we take its dividend yield to be the dividends paid in 2001 divided by the $12 / 31 / 00$ price, as reported in the CRSP data. The Mutual Fund database includes both U.S. and Canadian mutual funds; we use the most recent disclosures as of 12/31/2000. The holdings data cover spot but not derivative holdings, which is why (as discussed in detail below) they cover the U.S. holdings of general-purpose, but not RSP, Canadian international-equity funds.

\section{Background}

We briefly summarize the relevant empirical literature on mutual funds in Section 3.1. In Section 3.2 we show that, for our sample, retirement accounts prefer capital gains over dividends, whereas non-retirement accounts have less or zero preference. Section 3.3 provides the necessary information on dividend arbitrage, with details collected in the Appendix.

\subsection{Literature}

Mutual funds have emerged as an ideal hunting ground for breakdowns of agency. This is partly because they present a classic principal/agent problem, partly because the trillions under management make even small breakdowns economically important, and partly because the data are so good. Also, the literature's skepticism about managers' ability to add value (e.g., Jensen, 1968) begs the question of what else they could try to 
do. Considering this context, our research question about a potential success of agency is a departure. In this section we run briefly through some of the findings that frame our own.

A primary focus of the literature on agency problems is the tradeoff between servicing current accounts and attracting new ones. Perhaps the best-known source of this tradeoff is the convex relation of new investment to recent performance (Ippolito, 1992, Goetzmann and Peles, 1997, Sirri and Tufano, 1998). The convexity links funds' risk choices to their expected future assets, and a growing literature (Brown, Harlow and Starks, 1996, Chevalier and Ellison, 1997, Busse, 2001, Nanda, Wang and Zheng, 2003) addresses the resulting effect on investment policies. Similarly, this convexity pushes a quarter's winning funds toward quarter-end purchases of stocks they already hold (Carhart, Kaniel, Musto and Reed, 2002).

Besides the flow/performance relation, another source of tradeoffs is capital-gains realizations. Funds accelerate the tax liabilities of their current taxable accounts when they realize capital gains (Jeffrey and Arnott, 1993, Dickson and Shoven, 1994), but by the same token they decelerate the tax liabilities of their future taxable accounts (Barclay, Pearson and Weisbach, 1998). This encourages more realizations by funds with better prospects for attracting new investment, and that is what we see empirically in the cross section (Barclay et al., 1998). It is not as clear whether this policy has its intended effect, because while Barclay et al. (1998) find that funds' growth rates respond negatively to capital gains' "overhang," Bergstresser and Poterba (2002) find little or no difference between the response of new retail investment, which they take to be largely taxable, and 
that of new institutional investment, which they take to be largely non-taxable, to the fund's tax burden.

Our empirical question concerns tradeoffs within funds' current accounts.

Differences between funds' current accounts have already been shown to be important in several respects. In Johnson (2003), investors with short horizons are shown to impose significant transactions costs on those with longer horizons. In several recent studies (Goetzmann, Ivkovic and Rouwenhorst, 2001, Chalmers, Edelen and Kadlec, 2001, Greene and Hodges, 2002) and many subsequent news reports, accounts trading on stale prices are shown to impose significant dilution costs on the remaining accounts. This is especially true for international funds (though perhaps less so for our FY 2003 sample period, when enforcement increased). And Christoffersen and Musto (2002) argue that accounts that survive more attrition are relatively less price sensitive, with implications for pricing policies.

\subsection{Relative Preferences of Retirement and Non-retirement Accounts}

Earlier work (e.g., Bergstresser and Poterba, 2002) shows that taxable accounts get more, after tax, from capital gains than from dividends, but retirement accounts do not. Thus, it would seem that taxable accounts prefer capital gains more than retirement

accounts do. But for two reasons, the opposite is true for our sample. The first reason is that retirement accounts pay a tax on cross-border dividends that they do not pay on capital gains. The second reason is that after 2002, taxable accounts marginal rates are the same for dividends and long-term capital gains. The next two sections document these reasons in detail. 


\subsubsection{Tax Retirement Accounts Pay on Cross-Border Dividends}

Three elements of tax law combine to create the tax that mutual funds' retirement accounts pay on cross-border dividends. First, major economies generally tax dividends headed over the border (see, e.g., Callaghan and Barry, 2003). The tax rate can depend on bilateral treaties; the usual rate, and the rate for the U.S./Canada border, is $15 \%$. Second, taxable accounts generally get a full offsetting credit for foreign tax paid, so for them the tax generally means nothing. By contrast, non-taxable accounts get no credit, so to them this is a net tax. Third, dedicated pension funds can apply for exemption from the tax, but mutual funds cannot, not if they are open to taxable accounts. Few if any U.S. funds - and none of the funds in our sample - are structured to be exempt from withholding. The structure of Canadian mutual funds is quite different in this respect, a difference we explain and exploit below in Section 6.

How economically significant is the tax that cross-border dividends impose on retirement accounts? Table 1 shows $\$ 330.4 \mathrm{MM}$ of withholding in FY 2003 on $\$ 127.0 \mathrm{~B}$ of average total net assets, or $26 \mathrm{bp}$ per year. At this rate, retirement savers lose $4 \%$ of their international-equity savings over a 30 -year career. ${ }^{3}$ As $4 \%$ is in the neighborhood of a year of spending from retirement savings, this is an economically significant impact on U.S. consumers.

\subsubsection{Taxation of Dividends and Capital Gains in FY 2003}

How does the preference of international funds' retirement accounts for dividends compare to that of its taxable accounts? Our sample period is FY 2003, so the relevant

\footnotetext{
${ }^{3}$ A saver investing evenly over 30 years has the average dollar invested 15 years, and $15(26 \mathrm{bp})=3.9 \%$.
} 
question is how the tax code of this period treats the dividends and capital gains of retirement and non-retirement accounts. The sample falls primarily in one tax regime but spills a little into another; four fifths of the sample (i.e. $79 \%$ of the fund-months) are in 2003 and the remaining fifth in 2002, and the tax regime changes after 2002. Thus our primary interest is in after-tax returns in the 2003 regime, but the earlier regime is worth reviewing.

For retirement accounts, the answer is simple and the same for both 2003 and earlier: capital gains are better. This is because these accounts pay one tax at retirement on accumulated dividends and capital gains, but they pay an extra tax, the foreign tax, on the dividends. The first column of Table 2, Panel A, illustrates this. If we let $\tau_{\mathrm{T}}$ be the tax applied at retirement, $\tau_{\mathrm{F}}$ be the foreign tax and $n$ be the number of shares of a mutual fund, then the value to a share in a retirement account of an additional $\$ 1$ of dividends is $\$ 1\left(1-\tau_{\mathrm{T}}\right)\left(1-\tau_{\mathrm{F}}\right) / n$, whereas the value of an additional $\$ 1$ of capital gains is $\$ 1\left(1-\tau_{\mathrm{T}}\right) / n$. So the retirement accounts of international funds, whatever the tax brackets of their owners, strictly prefer capital gains to dividends.

For non-retirement accounts, the answer is simple for 2003 and murkier for 2002. In 2003 , these accounts are largely indifferent between dividends and capital gains. This is because the 2003 tax code equalizes the tax rate on "qualified" dividends with the rate on capital gains distributions and long-term capital gains. Since international funds' dividends are overwhelmingly "qualified", this means that taxable accounts pay exactly or nearly the same rate on dividends, capital-gains distributions and long-term capital

\footnotetext{
${ }^{4}$ For example, $100 \%$ of the ordinary dividends paid in 2003 by the largest international fund, American Funds' EuroPacific Growth Fund, are qualified (from the tax information on the American funds website, www.americanfunds.com).
} 
gains. In principle an investor might lower his expected tax rate on a capital gain by deferring redemption but he cannot possibly lower it more than the maximum rate of $15 \%$, and since $15 \%$ is the standard value for $\tau_{\mathrm{F}}$, this means that even with perfect foresight and planning he cannot prefer capital gains over dividends more than retirement accounts do. ${ }^{5}$ And perfect planning is not feasible with mutual-fund shares anyway, since mutual funds realize and distribute capital gains eventually and on the same schedule for all their shareholders. Thus, in the new tax regime, non-retirement accounts are indifferent, or at least more indifferent than retirement accounts, between dividends and capital gains.

For comparison with the retirement case, we present non-retirement accounts analogously in the second column of Table 2, Panel A, denoting the tax rates on dividends and capital gains with $\tau_{\mathrm{D}}$ and $\tau_{\mathrm{G}}$, respectively. These are about the same for 2003, but for 2002 they are different for higher-income investors. The tax situation for 2002 is essentially the one described by Bergstresser and Poterba (2002), who observe that investors in higher tax brackets earn more, post-tax, from long-term capital gains than from dividends. They also observe that the median mutual-fund dollar appears to come from such a bracket, though it is much less likely that the median mutual fund investor does. ${ }^{6}$ So in 2002 some non-retirement accounts share retirement accounts' aversion to dividends, and some do not.

\footnotetext{
${ }^{5}$ That is, a retirement account values $\$ 0.85$ of capital gains the same as $\$ 1$ of dividends, and the nonretirement account values $\$ 0.85$ of capital gains at no more than $\$ 1$ of dividends. See Blouin, Raedy and Shackelford for a catalogue of capital-gains-tax reduction tactics.

${ }^{6}$ The characterization of the median mutual-fund investor in the 2003 Mutual Fund Fact Book puts the median investor in a low bracket. The median investor is married with a household income of $\$ 62,100$, as of 2001. In 2001 (and also 2002), a married household with two kids, standard deductions and that income would have been in the $15 \%$ tax bracket.
} 
To summarize, all retirement investors prefer capital gains to dividends for our whole sample. Also, they prefer less foreign withholding tax. In contrast, all nonretirement accounts have less or zero preference between dividends and capital gains for four fifths of our sample, and for many this holds in the remaining fifth as well. Also, non-retirement accounts are indifferent to foreign withholding tax. Thus, funds benefit their retirement accounts in our sample period by reducing dividend yield and foreign withholding tax.

\subsection{Dividend Arbitrage}

There is one thing fund managers can do to help their non-taxable accounts with respect to this tax, and that is dividend arbitrage. The basic idea of cross-border dividend arbitrage (see McDonald, 2001, and Dai and Rydqvist, 2002) is to move shares back to their home countries for the record dates of their dividends, and to split the resulting tax savings through the pricing of the transaction. If the pricing gives the fund manager all the tax savings, then it eliminates the tax on non-taxable accounts, while having no effect on taxable accounts. However, if the pricing gives less than all of the tax savings, then it reduces the tax on non-taxable accounts, while having a negative effect on taxable accounts.

To show this formally, we can go back to Table 2, and consider what happens if the fund arbitrages a fraction $a$ of its dividend income of 1 . That is, the fund takes $a$ of the dividend-paying shares and transfers them to an investor in the shares' home country. Because this foreign investor is not withheld, he gets their full cash dividend of $a$, rather than the $a-\tau_{\mathrm{F}} a$ cash that the fund would have received. Therefore, ignoring the tax credit for the moment, the gains from trade are $\tau_{\mathrm{F}} a$, and we can denote the fund's share of these 
gains with $x$ : the fund gets $a-\tau_{\mathrm{F}} a+x a$ in cash and the foreign investor gets $\left(\tau_{\mathrm{F}}-x\right) a$.

Nobody gets a tax credit on the arbitraged portion, because no foreign tax was paid. The resulting values for retirement and non-retirement accounts are in Panel B of Table 2.

What Table 2, Panel B makes plain is that retirement accounts benefit from dividend arbitrage as long as $x>0$, but non-retirement accounts are hurt if $x<\tau_{\mathrm{F}}$. Thus, dividend arbitrage moves value from non-retirement to retirement accounts if and only if $0<x<\tau_{\mathrm{F}}$. Thus, the key empirical question is whether this is true.

We can observe directly whether $0<x<\tau_{\mathrm{F}}$ in the case of U.S. funds holding Canadian shares. We can do this because we have a proprietary database of dividendarbitrage transactions by U.S. investors in Canadian firms. These transactions are recorddate equity loans, and while the extensive form of the arbitrage, documented in the Appendix, is complex, the part we use is simple. For a given record date, the $\tau_{\mathrm{F}}$ in our example corresponds to $15 \%$ of the dividend, and the $x$ in our example corresponds to the lending fee in the proprietary data. So we can easily and unambiguously compare the U.S. investors' arbitrage revenues to the tax savings at stake.

This comparison is a big departure from the literature. The many studies of dividend-arbitrage topics have uncovered much (see Elton, Gruber and Blake, 2002, for a review), but they do not show, as we do, what dividend arbitrageurs actually get. It is generally unclear whether arbitrage is even feasible at all, since these studies rely on anonymous transactions in spot markets, where trading spreads can easily overwhelm the targeted tax savings. For example, if a firm pays a $2 \%$ dividend in quarterly installments, then the targeted tax savings on a record date is $15 \%$ of $0.50 \%$, or $0.075 \%$, which is 3 cents on a $\$ 40$ stock. Considering how big trades have to be to make economic sense 
(n.b., the trades in our proprietary data are typically millions of dollars), a roundtrip transaction cost smaller than this seems highly unlikely. This transactions-cost problem does not arise with equity loans because they do not convey economic exposure, and thus do not incur the adverse selection costs associated (e.g., Bagehot, 1971) with conveying economic exposure.

To summarize, mutual funds damage the after-tax returns of their non-taxable accounts, but not their taxable accounts, when they increase the dividend yields of their cross-border holdings. Dividend arbitrage may undo some of this damage, but if it doesn't undo all of it then it does new damage to taxable accounts, in which case funds face conflicting preferences among their shareholders. This raises the two empirical questions we address next: what does dividend arbitrage accomplish, and what do funds do?

\section{What does Dividend Arbitrage Accomplish?}

Dividend arbitrage converts tax credits that only taxable accounts value into cash that all accounts value. The rate of this conversion determines whether funds trade off the utilities of taxable and non-taxable accounts when choosing their dividend yields. In this section we determine this conversion rate by comparing tax credits to arbitrage revenues, using our proprietary data on U.S. investors in Canadian shares. In addition to these results on loan pricing, we also present results on loan volume from the UK market. 


\subsection{Pricing of Canadian Dividend Arbitrage}

The tax credit is simply $15 \%$ of the dividend amount. That is, if the fund does not arbitrage, it gets $85 \%$ of the dividend in cash and $15 \%$ as a credit. The arbitrage revenue that it compares to is the lending fee. That is, if the fund does arbitrage, it gets $85 \%$ of the dividend in cash (as a reimbursement from the borrower, rather than as a payment from the issuer) plus the lending fee, but no credit. Our database provides $\$ 676 \mathrm{MM}$ of record-date lending of Canadian shares, which includes 223 loans on 34 different record dates; for each record date $i$ we calculate a single fee $F_{i}$ by value-weighting the fees of the loans originated then. ${ }^{7}$ Since this fee is per dollar of stock value, it compares to the dividend per dollar of stock value, i.e., the dividend yield, so for record date $i$ we let $Y_{i}$ be the dividend divided by the closing price on the day before the record date (the price that is used to determine the collateral for the loan). With these definitions, the empirical question is whether $F$ is less than $15 \%$ of $Y$.

The answer to this question is plainly yes. Looking across the 34 record dates, plotted as Figure 1, $F / Y$ is less than $15 \%$ every time, with a maximum of $12 \%$. The mean and median are $4 \%$ and $2 \%$, respectively, and it appears from the figure that arbitrage revenue is zero for dividends below $30 \mathrm{bp}$ or so, suggesting that fixed transactions costs make these dividends infeasible to arbitrage. We can explore this more rigorously by regressing $F$ on $Y$, which (as in McDonald, 2001) gives an intercept representing the fixed transactions cost, and a slope representing the lender's recovery of the marginal unit of dividend yield We convert both to basis points by multiplying by 10,000 , and we get (standard errors in parentheses):

\footnotetext{
${ }^{7}$ The lending fee in our database is an annual rate, and it applies to collateral equal to $102 \%$ of the shares' value, so the fee we use is $102 \%$ (annual rate)( $n / 360)$, where $n$ is the number of calendar days from the record date to the next business day.
} 
$F_{i}=\quad-2.9$
$+0.1026 Y_{i}$

$(0.017)$
$\mathrm{R}^{2}=53.8 \%$

$\mathrm{N}(\mathrm{obs})=34$

The slope coefficient is both significantly greater than 0 (t-statistic 6.11$)$ and significantly less than $15 \%$ (t-statistic 2.82$),{ }^{8}$ which indicates a recovery that is positive but less than full, and the intercept is significantly negative with a point estimate of $-3 \mathrm{bp}$, consistent with a breakeven yield of $30 \mathrm{bp}$ (i.e., recovering $10 \%$ of $30 \mathrm{bp}$ offsets $-3 \mathrm{bp}$ ).

\subsection{Volume of UK Dividend Arbitrage}

Our database of loan prices limits the results on dividend-arbitrage pricing to Canada. However, we can explore dividend-arbitrage volume elsewhere in the world. Specifically, we can measure the effect of dividends on lending volume in the United Kingdom because the UK clearing corporation, CRESTCO, reports daily lending volume for the major UK stocks, the FTSE 250 and 100. Because CRESTCO intermediates nearly all the outstanding shares of these listings, this shows us the economy-wide, not just single-lender, response of lending to dividends.

The UK tax regime differs somewhat from the Canadian regime ${ }^{9}$ but the economics of dividend arbitrage are qualitatively the same. Non-UK accounts that cannot get the tax credit, such as US mutual funds' retirement accounts, benefit from moving their shares to UK investors and sharing the regained credit. Since the credit increases with the dividend yield, both the demand for and the supply of arbitrage capital should increase with the yield. Thus, we can test whether arbitrage of UK dividends

\footnotetext{
${ }^{8}$ Because the observation in the upper right of Figure 1 appears influential, we rerun the regression with this observation removed and we find the same thing: the slope is significantly greater than 0 (t-statistic 3.43 ) and significantly less than $15 \%$ (t-statistic 4.12 ).

${ }^{9}$ A brief overview of the effective UK-US Tax Treaty is provided at www.ici.org/issues/glo/arcfsrv/01_uk_tax_treaty.html. To summarize, if a UK company pays a $\$ 90$ dividend, it also pays $\$ 10$ to the UK tax authority. Both taxable and non-taxable accounts receive the $\$ 90$, but taxable accounts also get a tax credit for the $\$ 10$ paid to the tax authority.
} 
operates through the lending market by testing whether lending volume increases with yield.

To run this test, we first identify all dividends covered by the sample, which runs from $9 / 01 / 03$ to $6 / 03 / 04$. For each dividend we define four variables: $D Y$, the dividend amount divided by the cum-dividend price, $R D L O A N$, the number of the issuer's shares loaned on the record date, $A V G L O A N$, the average number of the issuer's shares during the sample period, and SHARES, the number of the issuer's shares held through CRESTCO on the record date. The statistical question is whether RDLOAN increases with $D Y$, controlling for the secular level of borrowing demand captured by AVGLOAN. We control for $A V G L O A N$ two ways, by subtracting it from the left-hand side, and by including it on the right-hand side. The point of calculating SHARES is that share ownership, and therefore demand for arbitrage by current investors, increases with SHARES, so we should control for it as well to separate its effect from that of DY. Regression results are in Table 3.

All tests show a strong relation between lending volume and dividend yield. In Panel A, which represents all stocks in the database, the coefficients of about 2 billion on $D Y$ in the first two regressions associate a $100 \mathrm{bp}$ increase in yield with $1 \%$ of 2 billion, or 20 million increase in loaned shares. The coefficient of about 1 in the third regression associates a $1 \%$ increase in yield with a $1 \%$ increase in shares outstanding loaned. Panel $\mathrm{B}$ repeats the regression with the closed-end funds removed and the same results obtain.

To summarize, dividend arbitrage is an important element of capital markets, but dividend arbitrage revenue falls short of recovering the cross-border dividend tax. A fund's retirement accounts thus face a net tax on cross-border dividends, so the fund's 
manager faces a tradeoff between the preferences of his retirement and taxable accounts. Retirement accounts prefer lower withholding tax and lower dividend yield, so if funds' investment policies reflect their shareholders' preferences, we should see withholding tax and dividend yield go down as the proportion of retirement money goes up. The next section tests these predictions.

\section{Cross Section of Equity Funds}

We take our predictions to the sample of 64 large international equity funds. For each fund we have the proportion of the fund that is defined-contribution retirement money as of 12/31/02, and we have FY 2003 figures for dividends, withholding taxes and total net assets. Therefore, we see directly whether dividends and withholding taxes, per dollar of shareholder money, decrease as retirement money, per dollar of shareholder money, increases. As a robustness check, we then take our test design to the sample of domestic funds, where low dividends do not favor retirement accounts.

The variables we need are easily calculated. For fund $i$, let $R_{i}$ be the proportion of its assets that was DC retirement money as of $12 / 31 / 02$, i.e., the DC figure for that fund as reported by Pensions and Investments divided by its 12/31/02 total net assets. Also, let $A_{i}$ be its average total net assets during its FY 2003, defined as the average of its total net assets as of the beginning, middle (i.e., semiannual) and end of FY 2003, and let $D_{i}$ and $W_{i}$ be its total dividend income and foreign withholding tax, respectively, during FY 2003. With this notation, the hypothesis to test statistically is whether $D / A$ and $W / A$ go down as $R$ goes up. 
We test the hypothesis with simple regressions of $D / A$ and $W / A$ on $R$, reported in Panel A of Table 4. Both regressions reject the null, showing significant negative relations. Thus, dividend yields and withholding taxes fall as retirement money rises, as they would if managers balance the preferences of their shareholders.

The hypothesis also makes a prediction for the relation between withholding taxes and dividends. Because dividend arbitrage benefits retirement accounts at the expense of non-retirement accounts, and because it reduces $W$ relative to $D$, we should also expect $W / D$ to fall as $R$ rises. We test this with an analogous regression, reported in the same panel. In this case we find borderline statistical significance, with a p-value of $6.7 \%$.

A potential concern with the Panel A regressions is that they do not account for the subtypes of international equity funds. Retirement investors might sort into international-fund subtypes that have low dividends for some other reason, and that might drive our result. To test our hypothesis against this possibility, we repeat the regressions with indicator variables for the various subtypes. We have two sources of subtypes, Lipper's index groupings and Morningstar's style boxes.

The Lipper subtypes correspond to their indices of international-equity mutual fund returns. The sample includes funds in five of these subtypes: International, Emerging Market, European, International Small Cap, and Pacific. Accordingly, we rerun the three regressions with indicator variables for each type except International. The results, in Panel B of Table 4, are similar to those from the simple regressions. The relations of withholding tax and dividends to the proportion of retirement money are significantly negative, and the relation of withholding tax per dollar of dividends is negative but less significant, now with a p-value of $10.7 \%$. So at these rejection levels, 
the regressions bear out the hypothesis even when we control for subtypes within the fund category.

Morningstar style boxes are a 3 by 3 matrix, \{Value, Blend, Growth $\}$ by $\{$ Small Cap, Medium Cap, Large Cap\}. They are appealing for our purpose in that they are widely reported, but they have a drawback in that they introduce some endogeneity. This is because assignments to boxes are not by funds' stated objectives, but rather by their portfolio weights, so they are endogenous to the effect of dividend-yield objectives on portfolio weights. We employ them analogously to Panel B, with indicator variables for Value, Growth, Small-Cap and Large-Cap. The results, in Panel C of Table 4, are again similar to before, though significances have swapped. Now the relations of withholding tax and withholding tax per dollar of dividends are significantly negative at standard rejection levels, and dividend yield is negative with a p-value of $13.1 \%$, whose size may reflect endogeneity of style-box assignments to dividend yield.

An alternative explanation for the Table 4 results is that the observed relation reflects investors' preferences, rather than managers' adaptation to the composition of their assets under management. That is, retirement allocations correlate with dividend yields not because managers respond to their shareholders' preferences but because shareholders' preferences for their retirement savings correlate with dividend yield. This is a testable proposition because we can repeat the test with international funds replaced by domestic funds. The virtue of domestic funds, for this purpose, is that lower dividends do no favor for their retirement accounts, so if retirement allocations correlate with dividend yield it is for some other reason than managers responding to their shareholders' preferences. 
To test the hypothesis that retirement allocations to domestic funds correlate with dividend yield, we repeat the test of Table 4 on the analogous sample of domestic funds. Domestic funds are much more numerous than international funds, so this sample is much larger, 434 funds rather than 64 . As with the international funds, we collect the Morningstar style-box assignments for one set of controls, but for the other set we use the major ICDI fund categories rather than Lipper index groupings because for domestic funds, Lipper index groupings are largely the same as Morningstar style boxes. Since withholding tax is not an issue, the only dependent variable for each set of regressors is $D / A$. The results, in Table 5 , show no statistically significant relation, with or without the controls. Thus, the results in Table 4 are not a feature of funds in general, but of international funds in particular, further evidence for our hypothesis.

A remaining possible explanation for Table 4 is that investment policies line up with retirement allocations because investors impute expected investment policies into their retirement allocations. There is ultimately some amount of observational equivalence between the investor-driven and manager-driven explanations, but we view the investor-driven explanation as highly unlikely, for two reasons. First, we have detected no public awareness of the effect of cross-border taxation on retirement accounts. And second, if taxable and non-taxable allocations respond differently to this tax burden, one would also expect them to respond differently to better-known tax burdens, but from Bergstresser and Poterba (2002) it appears they do not.

To summarize, managers' investment policies reflect their investors' preferences. Policies grow more favorable to retirement accounts when they serve more retirement accounts. This is not what we would see if managers maximize their total returns, at least 
not the total returns the public sees. To do that, they would all avoid tax credits as much as possible, since the credits do not figure in the total returns the public sees even though

they are valuable to taxable accounts. In other words, managers would behave as if all of their money were retirement money, but we find that they don't. By the same token, the funds' objective is not after-tax returns either, because then they would behave as if all their money were taxable money, which they don't.

The immediate implications of our results are for mutual-fund investors. But due to the economic magnitude of retirement investing, they also have implications for aggregate cross-border investing. The next section addresses the effect of dividend yield on aggregate cross-border investing by U.S. institutions in general and mutual funds in particular, and it also compares this effect to the analogous effect in Canada, where the taxation of foreign and domestic dividends is different in a key way.

\section{Aggregate Investment}

Another way to relate shareholders' preferences to their funds' policies is to compare the weights that U.S. and Canadian mutual funds put on U.S. and Canadian stocks. This is because the Canadian international funds that hold equities have no retirement accounts, so they all have $R=0$, whereas the U.S. funds have $R>0$. That is not to say that Canadians do not put retirement money in international mutual funds; they do, but Canadian tax law directs this money to funds that hold derivatives rather than equities. In this section we discuss the important regulatory background and then test predictions for the effect of dividend yield on the difference between Canadian and U.S. weights in Canadian and U.S. stocks. 


\subsection{Tax-Induced Preferences of Canadian Mutual-Fund Accounts}

Mingling of retirement and non-retirement savings is significantly reduced in Canada retirement savings by Retirement Savings Plan, or RSP, funds. RSP funds do not hold foreign equities, due to Canada's Foreign Content Rule. This rule grants retirementsavings tax treatment only to funds invested at least $70 \%$ in Canada, but a fund satisfies this rule if it invests in Canadian securities, such as government bonds, and swaps their returns for cross-border returns with a Canadian swap counterparty.

This may seem obscure but it has two important effects. First, because RSP funds hold bonds and swaps rather than equities, their holdings do not show up on the database of equity holdings. Second, because non-RSP funds do hold equities, the cross-border equity holdings that our database reports are by funds with significantly less retirement money.

The preferences of the U.S. and the Canadian mutual-fund accounts are further differentiated by Canada's Dividend Tax Credit. This is a tax-rate reduction enjoyed by taxable Canadian accounts, but not U.S. accounts, on Canadian dividends, but not U.S. dividends (see, e.g., Lakonishok and Vermaelen, 1983, and Booth, 1987). Putting all this together, less of the Canadian investment pays an extra tax on U.S. dividends, and some pays a reduced tax on Canadian dividends. Meanwhile, some of the U.S. accounts pay an extra tax, and none pay a reduced tax, on Canadian dividends, and none of them pay an extra tax on U.S. dividends.

For illustration, consider the effective marginal rates from 2001, the year of the dividends we look at. For that year, Canadians in the highest bracket pay $46 \%$ on U.S. dividends, $31 \%$ on Canadian dividends, and $23 \%$ on both Canadian and U.S. capital 
gains. ${ }^{10}$ A U.S. investor in the highest bracket pays $39 \%$ on all dividends and $20 \%$ on all long-term capital gains. ${ }^{11}$ So both the U.S. and the Canadian investor pay about twice as much tax on U.S. dividends as on U.S. or Canadian capital gains, but the Canadian taxable investor pays on Canadian dividends only $2 / 3$ the tax she pays on U.S. dividends. So if funds' investment policies reflect their shareholders' preferences, then the dividend yield of a U.S. stock should have little effect on its relative appeal to U.S. and Canadian funds, but the dividend yield of a Canadian stock should boost its relative appeal to Canadian funds.

\subsection{Empirical Test}

The goal of the test design is to relate the difference between U.S. and Canadian portfolio weights of a U.S. or Canadian stock to the stock's dividend yield and nationality. The sample of stocks is all U.S. and Canadian stocks on the SEC's Official List for 12/31/00. For each stock $i$ we calculate the explanatory variables: the annual dividend $A D Y_{i}$ is its 2001 dividends divided by its $12 / 31 / 00$ price, and $C D N_{i}$ is 1 if the stock is Canadian, and 0 otherwise. We then calculate five portfolio weights, all as of 12/31/00: $V W_{i}$ is its value weight in this universe, $U S 13 F_{i}$ and $C D N 13 F_{i}$ are its weights in the aggregated $13 \mathrm{f}$ filings of U.S. institutions and Canadian institutions, respectively, and $U S M F_{i}$ and $C D N M F_{i}$ are its weights in the aggregated filings of U.S. and Canadian mutual funds, respectively (for each fund active as of 12/31/00, the last filing dated on or before 12/31/00).

\footnotetext{
${ }^{10}$ From the Appendix to Chapter 1 of Ross, Westerfield, Jaffe and Roberts (2001) and T1 General 2001 Income Tax and Benefit Package for Ontario.

${ }^{11}$ From 20011040 Forms and Instructions, tax rate schedules on page 71 and capital gain tax worksheet on page 34 .
} 
To test our hypothesis, we regress CDN13F-US13F and CDNMF-USMF on CDN, $A D Y$ and $C D N^{*} A D Y$. With this model, $C D N$ picks up non-dividend sources of home bias and $A D Y$ picks up dividend preference across stocks in general, leaving the interaction term to pick up the preference for Canadian dividends in particular. A benefit we gain by looking at the difference between two groups of institutional investors is that the regression does not pick up general preferences of institutional investors, which Dahlquist and Robertsson (2001) conjecture could explain their results on ownership of Swedish stocks. That is, the general preferences of institutional investors are on both sides of the difference, so they wash out. Results are in the first rows of Panels A and B of Table 6.

What we find is a significant effect of Canadian firms' dividends, pushing Canadian stocks from U.S. funds to Canadian funds, and no significant effect of U.S. firms' dividends. This holds for all institutions combined but is strongest for mutual funds in particular. To separate the effect on U.S. funds from the effect on Canadian funds, we rerun the regressions with $C D N M F-U S M F$ decomposed into $C D N M F-V W$ and USMF- $V W$ and CDN13F-US13F decomposed into CDN13F-VW and US13F-VW. The results, in the second and third rows of the same panels, show a much larger effect on the Canadian portfolio weights, which is what one would expect if a quantity of shares moved from the U.S. portfolio to the much smaller Canadian portfolio.

To summarize, this section finds additional evidence that funds' investment policies reflect the preferences of their investors. Differing tax laws and retirement schemes impart differing preferences on the fund accounts represented by the holdings data, and the funds' investment policies reflect these differences. As before, this is not 
what would obtain if managers were simply maximizing their reported total returns. Canadian funds' total returns do not reflect their shareholders' tax credits, but their investment policies do.

\section{Summary and Conclusion}

If a fund's shareholders knew what its manager knew, they would not agree what its manager should do. In particular, retirement and non-retirement accounts have conflicting preferences, and one of these conflicts concerns cross-border dividends. The tax credits they produce are useless to retirement accounts but useful to non-retirement accounts, so a manager cannot maximize expected utility of both account types unless he can convert the credits into their full cash value through dividend arbitrage. Our first main empirical result is that this conversion is significantly less than full, so managers of international-equity funds have a choice to make, if they are maximizing with their shareholder preferences in mind. They can favor their retirement accounts with lower dividends and tax credits, so if funds' investment policies reflect their shareholders, then these quantities should go down as retirement money goes up.

Our second main empirical result is that in the cross section of international funds, this is exactly what we find. As the proportion of retirement money goes up, dividend yield goes down, foreign tax credits go down, and tax credits per dollar of dividends go down. This is true even if we control for the subtypes of international funds, both the Lipper index groups and the Morningstar style boxes, and it is not true for domestic funds, where the tax-efficiency argument does not apply. So the managers' objective is not the returns enjoyed by retirement accounts, or the returns enjoyed by non-retirement 
accounts, but somewhere in between, depending on how much retirement money resides in their particular funds. Similarly, we find that the differing investment policies of U.S. and Canadian funds match the differing preferences induced by the two regulatory systems.

Our findings open up a new dimension in the analysis of mutual funds. We trace an important cross-sectional variation among funds to the composition of their current investors. This is not an agency problem but rather the opposite, a successful delegation of investment decisions. This is not to say that money management does not exhibit agency problems, evidence of such problems is strong and diverse, but it does show that to at least some extent, we can understand what fund managers do by looking closely at what they are supposed to do. 


\section{References}

Bagehot, W., 1971. The only game in town. Financial Analysts Journal 22, 12-14.

Barclay, M., N. Pearson and M. Weisbach, 1998. Open-end mutual funds and capital gains taxes. Journal of Financial Economics 49, 3-43.

Bergstresser, D., and J. Poterba, 2002. Do after-tax returns affect mutual fund inflows? Journal of Financial Economics 63, 381-414.

Blouin, J. L., J. S. Raedy and D A. Shackelford, 2004. Did dividends increase immediately after the 2003 reduction in tax rates? NBER Working Paper 10301.

Booth, L. D., 1987. The dividend tax credit and Canadian ownership objectives. Canadian Journal of Economics, May, 321-339.

Brown, K. C., W. V. Harlow and L. T. Starks, 1996. Of tournaments and temptations: An analysis of managerial incentives in the mutual fund industry. Journal of Finance 51, 85110.

Busse, J., 2001. Another look at mutual fund tournaments. Journal of Financial and Quantitative Analysis 36, 53-74.

Callaghan, S. R., and C. B. Barry, 2003. Tax-induced trading of equity securities: Evidence from the ADR market. Journal of Finance 58, 1583-1611.

Carhart, M., R. Kaniel, D. Musto and A. Reed, 2002. Leaning for the tape: Evidence of gaming behavior in equity mutual funds. Journal of Finance 57, 661-693.

Chalmers, J. M. R., R. M. Edelen and G. B. Kadlec, 2001. On the perils of financial intermediaries setting security prices: The mutual fund wild card option, Journal of Finance 56, 2209-2236.

Chevalier, Judith and Glen Ellison, 1997. Risk-taking by mutual funds as a response to incentives. Journal of Political Economy, 105, 1167-1200.

Christoffersen, S. E. K, and D. Musto, 2002. Demand curves and the pricing of money management. Review of Financial Studies 15, 1499-1524.

Dahlquist, M. and G. Robertsson, 2001. Direct foreign ownership, institutional investors, and firm characteristics. Journal of Financial Economics 59(3), 413-440.

Dai, Q., and K. Rydqvist, 2002, How do buyers and sellers divide the surplus? Evidence from tax arbitrage, Working paper, Norwegian School of Management and Binghamton University. 
Dickson, J. M., and J. B. Shoven, 1994. A stock index mutual fund without net capital gains realizations. NBER Working Paper 4717.

Elton, E. J., M. J Gruber and C. R. Blake, 2002. Marginal stockholder tax effects and exdividend day behavior - thirty-two years later. Working Paper, NYU and Fordham.

Eun, C. S., and S. Sabherwal, 2003. Cross-border listings and price discovery: Evidence from U.S. listed Canadian stocks. Journal of Finance 58, 549-575.

Geczy, C., D. Musto, and A. Reed, 2002. Stocks are special too: An analysis of the equity lending market. Journal of Financial Economics 66(2-3), 241-269.

Goetzmann, W. N., and N. Peles, 1996. Cognitive dissonance and mutual fund investors. Journal of Financial Research 20, 145-158.

Goetzmann, W, Z Ivkovic and K.G. Rouwenhorst, 2001. Day trading international mutual funds: Evidence and policy solutions. Journal of Financial and Quantitative Analysis 36, 287-309.

Greene, J. T., and C. W. Hodges, 2002. The dilution impact of daily fund flows on openend mutual funds. Journal of Financial Economics 65, 131-158.

Ippolito, R., 1992. Consumer reaction to measures of poor quality: Evidence from the mutual funds industry. Journal of Law and Economics 35, 45-68.

Jeffrey, R., and R. Arnott, 1993. Is your alpha big enough to cover its taxes? Journal of Portfolio Management 19, 15-25.

Jensen, M., 1968. The performance of mutual funds in the period 1945-1964. Journal of Finance 23, 389-416.

Johnson, W., 2003. Predictable investment horizons and wealth transfers among mutual fund shareholders. Journal of Finance, forthcoming.

Lakonishok, J., and T. Vermaelen, 1983. Tax reform and ex-dividend day behavior. Journal of Finance 38(4), 1157-1179.

McDonald, Robert, 2001. Cross-border investing with tax arbitrage: The case of German dividend tax credits. Review of Financial Studies 14(3), p. 617-658.

Nanda, V, Z. Wang and L. Zheng, 2003. Family values and the star phenomenon: Strategies of mutual fund families. Review of Financial Studies, forthcoming.

Ross, S., R Westerfield, J. Jaffe and G. Roberts, 2003. Corporate Finance, $3^{\text {rd }}$ Canadian Edition. McGraw-Hill, New York, NY. 
Sirri, E., and P. Tufano, 1998. Costly search and mutual fund flows. Journal of Finance $53,1589-1622$. 


\section{Appendix}

Suppose a U.S. mutual fund, call it Taxwise International Fund, has 100,000 shares of TransCanada Pipelines, paying C\$0.29/share to shareholders of record on 6/30/04. Absent arbitrage, Taxwise gets $(0.85)(\mathrm{C} \$ 0.29)(100000)=\mathrm{C} \$ 24,650$ in cash and the remaining $\mathrm{C} \$ 4,350$ as a credit. Here is a structure, represented in Figure A1, by which Taxwise converts the credit into some cash: ${ }^{12}$

A U.S. arbitrageur shorts 100,000 shares cum-dividend to a Canadian arbitrageur, and repurchases them ex-dividend, borrowing the shares from Taxwise. The U.S. arbitrageur earns market interest on the short-sale proceeds.

The arbitrageurs enter a swap whereby the Canadian pays his price return plus $\mathrm{C} \$ 24,650$, and gets market interest on the proceeds minus a discount $D$.

The U.S. arbitrageur pays $C \$ 24,650$ to Taxwise as reimbursement for the dividend, and also pays a lending fee $F$.

All put together, Taxwise exchanges the C $\$ 4,350$ credit for $F$ in cash, the U.S. arbitrageur makes $D-F$, and the Canadian arbitrageur makes $C \$ 4,350-D$. In our data we see the $\mathrm{C} \$ 4,350$ and the $F$, it's only the sharing $D$ between the arbitrageurs we don't see.

A key goal of this structure is for Taxwise not to loan directly to the Canadian. If it were to loan to the Canadian then he Canadian tax authority would oblige the Canadian to withhold from the dividend reimbursement just as TransCanada would withhold from the dividend. It is worth noting also that the hedge from the swap makes the Canadian ineligible for Canada's dividend tax credit (though the Canadian might evade detection by routing the swap through another party).

\footnotetext{
${ }^{12}$ Market participants tell us this is the popular structure.
} 
Table 1

Summary statistics for mutual-fund samples. 2002 DC and 2002 TNA are DC money and Total Net Assets as of 12/31/02, $A$ is average Total Net Assets across the beginning, middle and end of FY 2003, $D$ and $W$ are dividend income and foreign withholding in FY 2003, all in \$MM. $R$ is 2002 DC divided by 2002 TNA. Panel A covers the sample of 64 International funds, and Panel B covers the sample of 434 Domestic funds

\begin{tabular}{|c|c|c|c|c|c|}
\hline & Mean & Median & Min & Max & Total \\
\hline \multicolumn{6}{|c|}{ A. International } \\
\hline $2002 \mathrm{DC}$ & 591.4 & 96.0 & 3.8 & 11047.0 & 37847.8 \\
\hline 2002 TNA & 1829.7 & 553.0 & 108.8 & 24786.0 & 117101.8 \\
\hline$R$ & $24.0 \%$ & $17.5 \%$ & $0.5 \%$ & $87.8 \%$ & \\
\hline$D$ & 47.2 & 17.1 & 2.5 & 506.4 & 3021.6 \\
\hline$A$ & 1985.0 & 636.0 & 118.7 & 24911.6 & 127039.9 \\
\hline$W$ & 5.2 & 1.7 & 0.2 & 61.9 & 330.4 \\
\hline$D / A$ & $2.41 \%$ & $2.42 \%$ & $1.48 \%$ & $3.80 \%$ & \\
\hline$W / A$ & $26.3 b p$ & $25.8 b p$ & $12.9 b p$ & $41.2 \mathrm{bp}$ & \\
\hline$W / D$ & $10.9 \%$ & $11.1 \%$ & $6.4 \%$ & $14.0 \%$ & \\
\hline \multicolumn{6}{|c|}{ B. Domestic } \\
\hline $2002 \mathrm{DC}$ & 948.7 & 162.5 & 0.2 & 38012.0 & 411732.8 \\
\hline 2002 TNA & 3080.5 & 930.0 & 100.5 & 68145.5 & 1336918.5 \\
\hline$R$ & $24.7 \%$ & $18.0 \%$ & $0.0 \%$ & $100 \%$ & \\
\hline$D$ & 50.0 & 9.8 & 0.0 & 1395.6 & 21682.9 \\
\hline$A$ & 3472.8 & 991.7 & 103.1 & 80133.3 & 1507203.8 \\
\hline$D / A$ & $1.19 \%$ & $1.06 \%$ & $0 \%$ & $5.36 \%$ & \\
\hline
\end{tabular}




\section{Table 2}

Post-tax returns of accounts types. The value in a cell is the value to one share in an account of the type indicated at the top of the column that accrues from income into the fund, which has $n$ shares, of the type indicated at the left of the row. The tax rates applied to retirement accounts upon retirement is $\tau_{\mathrm{T}}$, the rates applied to dividend and capital-gains income of non-retirement accounts are $\tau_{\mathrm{D}}$ and $\tau_{\mathrm{G}}$, respectively, and the tax rate of foreign dividend withholding is $\tau_{\mathrm{F}}$. Panel A assumes no dividend arbitrage, and Panel B assumes arbitrage of a fraction $a$ of dividend income, where the fund receives $x$ of the dividend amount in cash in exchange for the credit.

\begin{tabular}{lll}
\hline & Retirement & Non-Retirement \\
\hline $\begin{array}{l}\text { A. No Dividend Arbitrage } \\
1 \text { of Dividends }\end{array}$ & $\left(1-\tau_{\mathrm{T}}\right)\left(1-\tau_{\mathrm{F}}\right) / n$ & $\left(1-\tau_{\mathrm{D}}\right) / n$ \\
1 of Capital Gains & $\left(1-\tau_{\mathrm{T}}\right) / n$ & $\left(1-\tau_{\mathrm{G}}\right) / n$ \\
& & \\
B. Arbitrage $a$ of Dividend & & $\left(1-a\left[\tau_{\mathrm{F}}-x\right]\right)\left(1-\tau_{\mathrm{D}}\right) / n$ \\
1 of Dividends & $\left(1-\tau_{\mathrm{F}}+a x\right)\left(1-\tau_{\mathrm{T}}\right) / n$ & $\left(1-\tau_{\mathrm{G}}\right) / n$ \\
1 of Capital Gains & $\left(1-\tau_{\mathrm{T}}\right) / n$ & \\
\hline
\end{tabular}




\section{Table 3}

Dividend yield and arbitrage volume in the United Kingdom. For a given dividend record date between 9/01/03 and 6/03/04, RDLoan is the number of the issuer's shares held through CRESTCO that were loaned that day. AvgLoan is the average number loaned for that issuer from $9 / 01 / 03$ to $6 / 03 / 04$. Shares is the number of the issuer's shares held through CRESTCO on the record date. DY is the dividend yield for the firm defined as the dividend divided by the cum-dividend price. Panel A has 443 observations and Panel B has 398 .

\begin{tabular}{llll}
\hline Dep. Variable & Intercept & $D Y$ & Shares \\
\hline A. All firms: & & & \\
RDLoan-AvgLoan & $-8.71 \mathrm{e}+06$ & $1.92 \mathrm{e}+09$ & 0.004996 \\
& $(-0.80)$ & $(3.37)$ & $(2.92)$ \\
RDLoan & $-6.04 \mathrm{e}+06$ & $2.51 \mathrm{e}+09$ & .01949 \\
& $(-0.50)$ & $(3.94)$ & $(10.19)$ \\
(RDLoan-AvgLoan)/Shares & -0.00093 & 1.1209 & \\
& $(-0.25)$ & $(5.59)$ & \\
& & & \\
B. All firms except closed-end funds: & & & 0.00486 \\
RDLoan-AvgLoan & $-7.50 \mathrm{e}+06$ & $1.98 \mathrm{e}+09$ & $(2.69)$ \\
& $(-0.62)$ & $(3.19)$ & .01926 \\
RDLoan & $-3.52 \mathrm{e}+06$ & $2.57 \mathrm{e}+09$ & $(9.55)$ \\
& $(-0.26)$ & $(3.71)$ & \\
(RDLoan-AvgLoan)/Shares & .000164 & 1.1507 & $(5.31)$ \\
\end{tabular}




\section{Table 4}

Tests for whether foreign equity funds' retirement tax efficiency increases with their retirement allocations. $R$ is the defined contributions reported by Pension and Investments on December 31, 2002 divided by the TNA reported in CRSP for the same time. These are the 64 foreign equity mutual funds with available data and TNA over $\$ 100$ million. $W$ and $D$ are Withholding Tax and Dividend Income, respectively, in FY 2003, and $A$ is average TNA over the same period. Panel A uses indicator variables for Lipper index groupings: Emerging, Europe, Small International and Pacific. Panel B includes indicator variables for fund types from Morningstar style-box assignments: Large, Small, Growth and Value. T-statistics are provided below in parentheses and italics, and for the coefficients on $R$, rejection of the null hypothesis that the true coefficient is non-negative (i.e., that the true relation between tax efficiency for retirement accounts and retirement allocations is non-positive) is indicated: $*$ denotes rejection at the $10 \%$ level, $* *$ at $5 \%$, and $* * *$ at $1 \%$.

\begin{tabular}{llll}
\hline Dep. Variable & $W / A$ & $D / A$ & $W / D$ \\
\hline A. No Controls: & & & \\
Intercept & 28.69 & 0.0256 & 0.112 \\
& $(24.06)$ & $(28.98)$ & $(36.99)$ \\
$R$ & -9.923 & -0.0060 & -0.014 \\
& $(-2.66)^{* * *}$ & $(-2.15)^{* *}$ & $(-1.52)^{*}$
\end{tabular}

\section{B. Lipper Index Controls:}

\begin{tabular}{|c|c|c|c|}
\hline Intercept & 28.376 & 0.0252 & 0.113 \\
\hline & (22.41) & $(26.71)$ & (34.28) \\
\hline$R$ & -8.171 & -0.0047 & -0.012 \\
\hline & $(-2.24)^{* *}$ & $(-1.75)^{* *}$ & $(-1.26)$ \\
\hline Emerging & 1.174 & 0.0035 & -0.01 \\
\hline & $(0.42)$ & $(1.66)$ & $(-1.43)$ \\
\hline Europe & 4.891 & 0.0028 & 0.004 \\
\hline & (1.57) & $(1.20)$ & $(0.54)$ \\
\hline Intl. Small & -2.177 & -0.0022 & 0.003 \\
\hline & $(-0.70)$ & $(-0.93)$ & $(0.34)$ \\
\hline Pacific & -11.801 & -0.0069 & -0.027 \\
\hline & $(-2.73)$ & $(-2.13)$ & $(-2.36)$ \\
\hline C. Morning & -Box Cont & & \\
\hline Intercept & 27.659 & 0.0267 & 0.104 \\
\hline & (11.58) & (16.67) & $(16.36)$ \\
\hline$R$ & -8.164 & -0.0029 & -0.020 \\
\hline & $(-2.12)^{* *}$ & $(-1.13)$ & $(-1.98)^{* *}$ \\
\hline Small & 0.922 & -0.0014 & 0.011 \\
\hline & $(0.19)$ & $(-0.42)$ & $(0.87)$ \\
\hline Large & 2.472 & 0.0003 & 0.008 \\
\hline & (1.03) & $(0.19)$ & $(1.28)$ \\
\hline Value & 0.730 & 0.0001 & -0.001 \\
\hline & $(0.28)$ & $(0.07)$ & $(-0.12)$ \\
\hline Growth & -3.905 & -0.0051 & 0.006 \\
\hline & $(-2.28)$ & $(-4.47)$ & (1.31) \\
\hline
\end{tabular}




\section{Table 5}

Tests for whether domestic equity funds' dividend yields relate to their retirement allocations. $R$ is the defined contributions reported by Pension and Investments on December 31, 2002 divided by the TNA reported in CRSP for the same time. These are the 434 domestic equity mutual funds with available data and TNA over $\$ 100$ million. $D$ is Dividend Income in FY 2003, and $A$ is average TNA over the same period. Panel B includes indicator variables for the fund types as assigned by ICDI: $A G$, for Aggressive Growth, $G I$, for Growth and Income, and $L G$, for Long-term Growth. Panel B includes indicator variables for fund types from Morningstar style-box assignments: Large, Small, Growth and Value. T-statistics are provided below and in italics and parentheses, and for the coefficients on $R$, rejection of the null hypothesis that the true coefficient is zero is indicated: * denotes rejection at the $10 \%$ level, $* *$ at $5 \%$, and $* * *$ at $1 \%$.

\begin{tabular}{|c|c|}
\hline Dep. Variable & $D / A$ \\
\hline \multicolumn{2}{|l|}{ A. No Controls: } \\
\hline \multirow[t]{2}{*}{ Intercept } & 0.0126 \\
\hline & $(22.88)$ \\
\hline \multirow[t]{2}{*}{$R$} & -0.0025 \\
\hline & $(-1.49)$ \\
\hline \multicolumn{2}{|c|}{ B. ICDI Category Controls: } \\
\hline \multirow[t]{2}{*}{ Intercept } & 0.0183 \\
\hline & $(19.77)$ \\
\hline \multirow[t]{2}{*}{$R$} & -0.0015 \\
\hline & $(-1.13)$ \\
\hline \multirow[t]{2}{*}{$A G$} & -0.0113 \\
\hline & $(-10.79)$ \\
\hline \multirow[t]{2}{*}{ GI } & -0.0000 \\
\hline & $(-0.01)$ \\
\hline \multirow[t]{2}{*}{$L G$} & -0.0075 \\
\hline & $(-7.39)$ \\
\hline \multicolumn{2}{|c|}{ C. Morningstar Style-Box Controls } \\
\hline \multirow[t]{2}{*}{ Intercept } & 0.0109 \\
\hline & $(19.38)$ \\
\hline \multirow[t]{2}{*}{$R$} & 0.0002 \\
\hline & $(0.26)$ \\
\hline \multirow[t]{2}{*}{ Small } & -0.0011 \\
\hline & $(-1.74)$ \\
\hline \multirow[t]{2}{*}{ Large } & 0.0050 \\
\hline & $(10.03)$ \\
\hline \multirow[t]{2}{*}{ Value } & 0.0063 \\
\hline & $(11.50)$ \\
\hline \multirow[t]{2}{*}{ Growth } & -0.0071 \\
\hline & $(-15.14)$ \\
\hline
\end{tabular}


Table 6

Canadian and U.S. institutional equity holdings related to dividend yields. $V W_{i}$ is the value weight of stock $i$ among all U.S.-listed stocks. From the $13 \mathrm{f}$ filings for 12/31/00 we calculate the aggregate portfolio of all reporting U.S. institutions, and the aggregate portfolio of all reporting Canadian institutions; $U S 13 F_{i}$ is the weight of stock $i$ in the former, and $C D N 13 F_{i}$ is its weight in the latter. From mutual funds' most recent portfolio disclosures as of 12/31/00 we calculate the analogous statistics $U S M F_{i}$ and $C D N M F_{i}$. The dividend yield of stock $i, A D Y_{i}$, is its 2001 dividends divided by its $12 / 31 / 00$ price. $C D N_{i}$ is 1 if stock $i$ is Canadian, and 0 otherwise. The table reports coefficients and t-statistics (below, in italics and parentheses) from regressions where the independent variables are $C D N_{i}, A D Y_{i}$ and $C D N_{i}{ }^{*} A D Y_{i}$, and the dependent variables are as indicated.

\begin{tabular}{lllll}
\hline Dep. Variable & Intercept & $C D N_{i}$ & $A D Y_{i}$ & $C D N_{i}^{*} A D Y_{i}$ \\
\hline A. All Institutions: & & & & \\
CDN13F $i^{-} U S 13 F_{i}$ & -0.00002 & 0.00082 & 0.00012 & 0.0977 \\
& $(-4.01)$ & $(14.9)$ & $(0.65)$ & $(25.0)$ \\
$C D N 13 F_{i}-V W_{i}$ & -0.00002 & 0.00077 & 0.00001 & 0.08933 \\
& $(-4.11)$ & $(13.7)$ & $(0.07)$ & $(22.3)$ \\
$U S 13 F_{i}-V W_{i}$ & -0.000001 & -0.00005 & -0.00011 & -0.00837 \\
& $(-0.44)$ & $(-2.13)$ & $(-1.33)$ & $(-4.94)$ \\
B. Mutual Funds: & & & & \\
$C D N M F_{i}-U S M F_{i}$ & -0.00009 & 0.00173 & 0.00013 & 0.25001 \\
& $(-7.23)$ & $(14.5)$ & $(0.26)$ & $(29.3)$ \\
$C D N M F_{i}-V W_{i}$ & -0.0001 & 0.001719 & -0.00017 & 0.2427 \\
& $(-6.71)$ & $(13.4)$ & $(-0.32)$ & $(26.5)$ \\
$U S M F_{i}-V W_{i}$ & -0.0000 & -0.00002 & -0.00029 & -0.00731 \\
& $(-0.00)$ & $(-0.36)$ & $(-1.68)$ & $(-2.38)$ \\
\hline
\end{tabular}




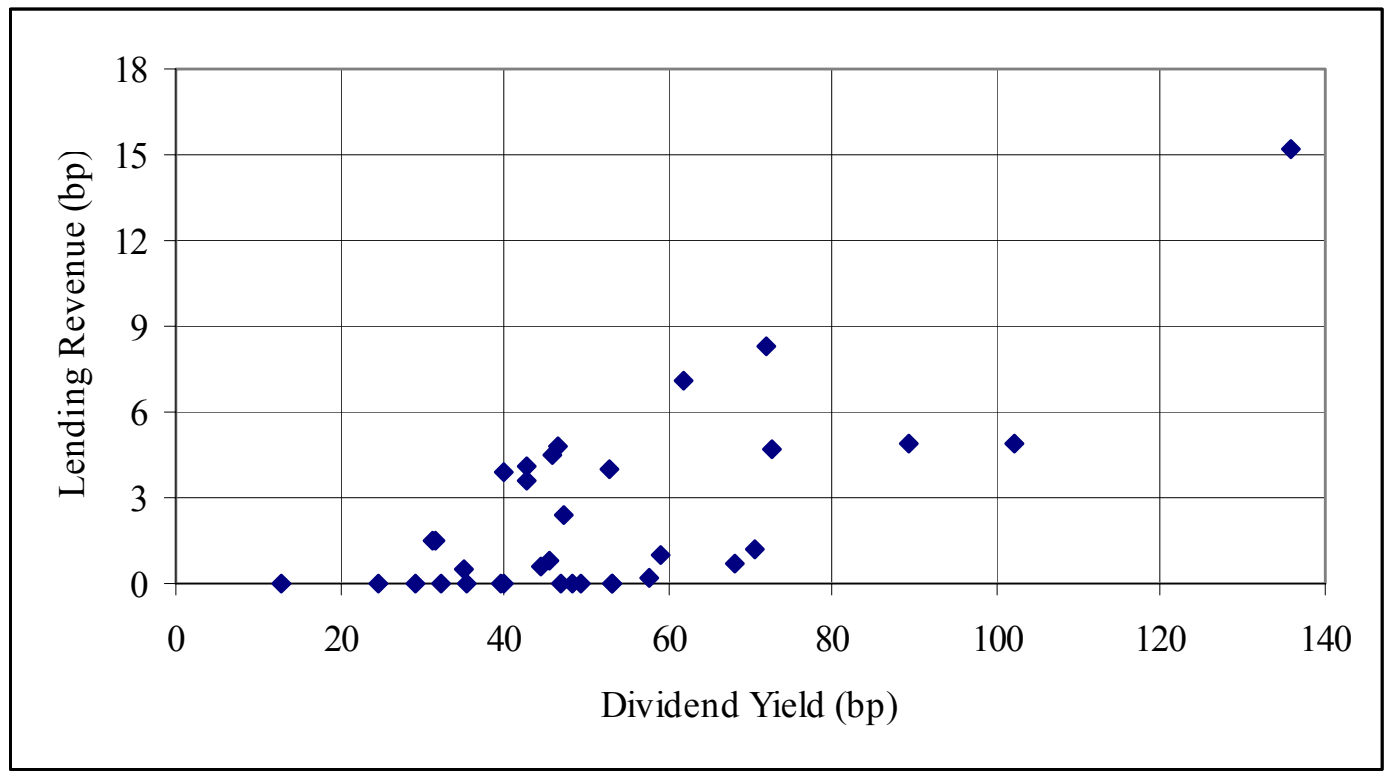

Figure 1: Lending Revenue v. Dividend Yield. For each record date, the dividend yield $Y_{i}$ is on the horizontal axis and the lending revenue $F_{i}$ is on the vertical axis. 


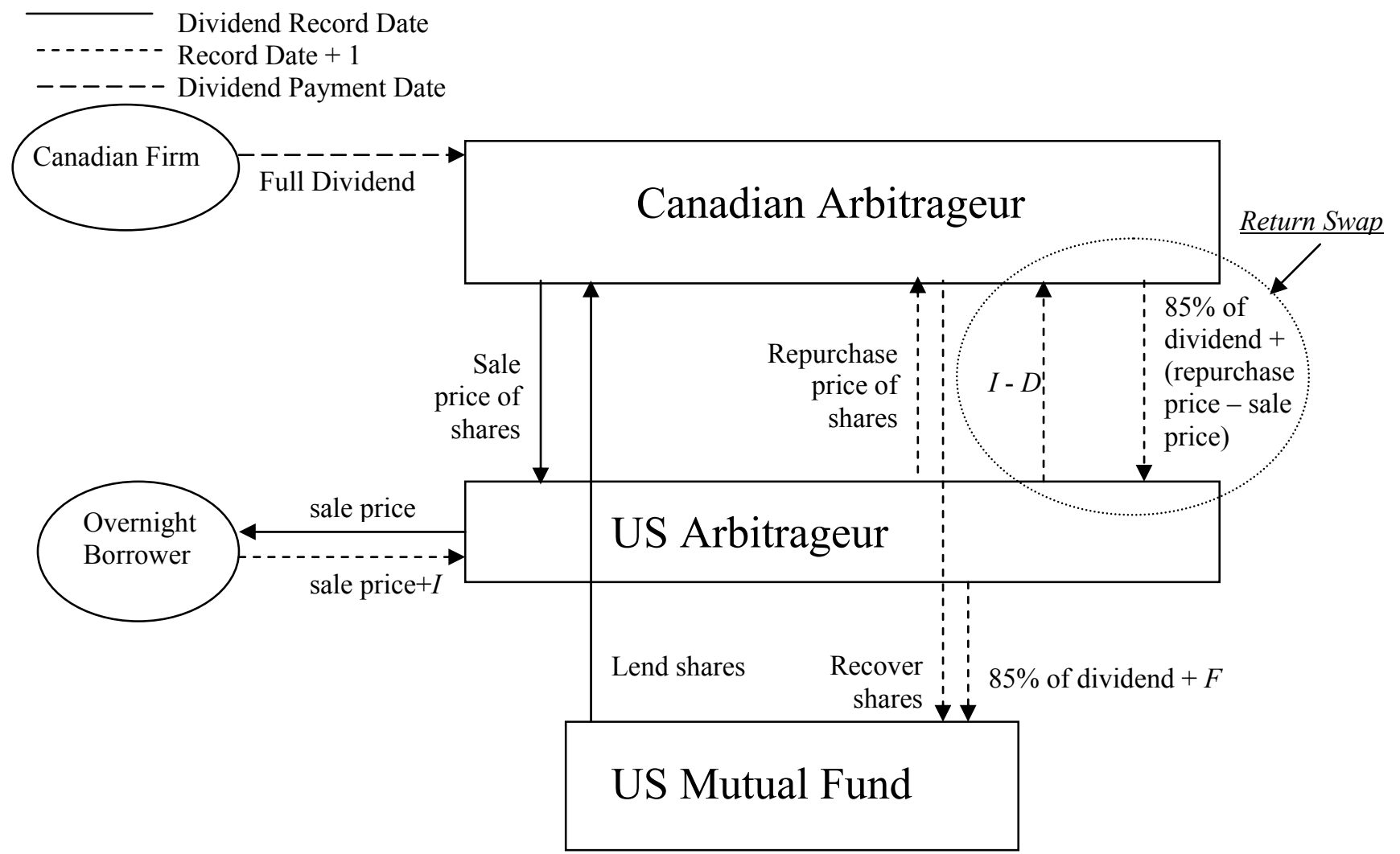

Figure A1. Structure of Withholding-Tax Arbitrage Between U.S. and Canada. 